\title{
Paideusis
}

\section{Wheels in the Head: Educational Authority, Freedom, and Culture from Socrates to Paulo Freire (Joel Spring)}

\section{Timothy J. Stanley}

Volume 9, Number 1, 1995

URI: https://id.erudit.org/iderudit/1073252ar

DOI: https://doi.org/10.7202/1073252ar

See table of contents

Publisher(s)

Canadian Philosophy of Education Society

ISSN

0838-4517 (print)

1916-0348 (digital)

Explore this journal

Cite this review

Stanley, T. (1995). Review of [Wheels in the Head: Educational Authority,

Freedom, and Culture from Socrates to Paulo Freire (Joel Spring)]. Paideusis, 9(1), 25-28. https://doi.org/10.7202/1073252ar 
a much more rigorous curriculum for girls as against the contemporary preoccupation with music and art. He was an early advocate of co-educational schools and an inspiration to those, especially women, who wanted to open up teacher training to women. With reference to the inequities of social class, he was a vigorous critic of the exclusiveness of the great English public schools like Eton. Though not wanting their abolition, he was an advocate of $r \in$ form, deploring both what he took to be the corruption of their everyday academic and leisure routines, and the privileged access of their graduates to power and influence in the life of the nation. He was equally critical of the elementary schools provided for the majority of working-class children, castigating them for the low attainment of many of their "graduates" and looking to the improvement of popular education through innovations in pedagogy and a raising of the professional standards of teachers. It was this which was his central preoccupation at the College of Preceptors.

Though a practitioner of private education himself, Payne nevertheless recognised the dark side of complete free enterprise in education when "any man or woman-indeed, any boy or girl-however ignorant, however lacking in moral principles or business acumen, could set up a school."

Though Payne's writings were influential in the wider educational milieu in England at the time and, posthumously, in the United States, he has largely been neglected by mainstream historians of education, possibly because he remained an outsider so far as the English political and educational establishments were concerned. Although unusual for a history of education, this book reads like a novel. Alongside the clear and scholarly exposition of Payne's educational theory, the accounts of his early life as a teacher and of his successful marriage and family life, as well as of the politics of his time at the College of Preceptors, are also clearly sketched in a work which will be of interest to anyone concerned with the work of schools and the education of teachers.

Reviewed by Harold Entwistle, Montreal

Joel Spring, Wheels in the Head: Educational Philosophies of Authority, Freedom, and Culture from Socrates to Paulo Freire. New York: McGraw Hill, 1994.

This book gets its title and central organizing principle from the educational ideas of the nineteenth-century libertarian-anarchist Max Stirner (1806-1856). Stirner opposed the rise of mass, state-controlled schooling on the grounds that students end up with "wheels in the head"-that is, ideas that control the individual, rather than the other way around. Stirner, a one-time associate of Karl Marx, applied his critique to radical educational ideologies as well as to those of rising states. Joel Spring builds on Stimer's metaphor to review and critique European philosophies of education ranging from those of Plato to Henri Giroux. The result is a highly accessible textbook that presents a refreshing argument about the liberating purposes of education.

A strength of Spring's work is the elegance of his descriptions of the various philosophies of education. Spring separates description from critique. For example, his first chapter, "Education and the Authoritarian State," reviews 
the educational theories of Plato and Anton Makarenko (with a slight detour on Adam Smith). It concludes with a section that establishes disturbing continuities between Platonic and Stalinist visions of education. According to Spring, both see the purpose of education as instilling belief in the infallibility of rulers, whether they be philosopher-kings or a proletarian party. Subsequent chapters build on the first by considering various ways of avoiding authoritarian approaches. These later chapters return to consider points raised earlier. For example, his discussion of the free school movement ends with a concluding section, "What would Socrates think?" (p. 65). A section on Allan Bloom notes the similarity and differences between Bloom's positions and those of libertarian-anarchists. According to Spring, Bloom shares with Stirner and others the view that people need to define their own educational projects and resist the impositions of state-control, but unlike the libertarian-anarchists, Bloom ignores the political nature of knowledge. The various parts of the book are well-stitched together: each chapter begins with a clear description of what he will do in it, and how it fits into the overall framework of the book.

Another strength of Wheels in the Head is its development of an argument about the nature of democratic education. Spring is not content merely to describe various philosophies of education and assess their strengths and weaknesses. He is also interested in identifying the elements of a democratic education. Indeed, he concludes with a list of characteristics for such an education. For Spring, democratic education insures that all citizens have equal political power. Thus, for example, following Paul Goodman, he argues that small schools (of perhaps fifty students at most) are conducive to real democratic control. Larger ones are simply too complicated.

Part of Spring's argument is concerned with the role of culture in schooling. Essentially, he holds that unless education provides students with the tools to understand mass culture critically, they will end up dominated by the values and beliefs of particular groups. He sees the control of multinational corporations over national systems of education as particularly insidious in this respect. His interest in culture leads him to review the arguments of Allan Bloom and E.D. Hirsch Jr. about education, culture, and cultural literacy. While highly critical of the arbitrariness of Hirsch's project, he is sympathetic to Bloom's argument about the centrality of culture to education. However, unlike Bloom, Spring admits that neither culture nor knowledge are politically neutral. An innovative aspect of Spring's argument is his view that issues of culture and education need to be considered in the context of an emerging global culture. While acknowledging that this culture is mainly based on American mass media, he sees it as providing opportunities to transcend the particularism of national cultures, especially for members of groups oppressed by racism. He finds that Afrocentric schools, for example, provide models for resisting cultural forms of domination while at the same time reaching out to a new African globalism. He makes a similar argument with respect to the need for women to approach issues from an international perspective.

Spring's concluding section examines the educational theories of Paulo Freire and the problems of achieving equality of political power in a global economy. To Spring, Freire's ideas speak to the liberating potential of education without falling into creating "wheels in the head." In part, he sees Freire's project of returning Eros, or pleasure, to education, as building on a line of 
argument he traces back through the views of Willhelm Reich and A.S. Neill. His discussion of political power and the global economy brings together many of the threads of the book by posing a series of questions including, for example, "Can education save the world" (p. 180)?

While in many ways modelling the value of critical reflection and that which is best in philosophy of education, Wheels in Head has some serious shortcomings. Although juxtaposing differing philosophies in innovative and provocatively jarring ways (few would immediately see a connection between Allan Bloom and Molefi Asante, for example), Spring's selections are eccentric to the point of seriously undermining the strengths of the work. This is especially evident in his consideration-more appropriately lack of consideration - of feminist educational theories. Spring's argument would occasionally benefit from feminist theoretical insights. Essentialism, for example, can be a "wheel in the head" and is an easy trap to fall into in reconstructing cultural identity. The omission of feminist theory is especially evident in part four of the book, "The Politics of Gender." The section begins with a review of the educational theories of John Locke and Jean-Jacques Rousseau and their views on the subordination of women. Spring follows this up with a discussion of Mary Wollstonecraft's rejection of Rousseau's notions of education for women and with a sketch of Pestalozzian theories of maternal love. His justification for this selection is that they represent the only two possible responses to Rousseau: either women, like men, are rational (Wollstonecraft) or they have ways of knowing that are different from men (Pestalozzi). This seems fair enough, but the only two modern theorists that he then considers in this section are Carol Gilligan and Camille Paglia. In this respect, one wonders if he has chosen these theorists because their positions are conducive to his argument, rather than because they represent the range of contemporary feminist educational philosophies. Nor are Spring's oversights restricted to feminist theories. He does not discuss humanist philosophies of education as exemplified by theorists such as Michael Oakeshott. Again here, I wonder if the reason for the exclusion is that Oakeshott's views of education do not fit into Spring's schema.

Another disappointment is Spring's discussion of Afrocentric education. While I have no disagreement with his argument that Afrocentric schools provide oppressed groups with an important model for globalism and for resisting cultural dominance, I was disturbed by the relative lack of critical engagement with the contents of the Afrocentric project, at least as described by Asante. Might not, for example, Africanism create "wheels in the head," even if they are preferable to those created by racist culture? I would have liked more discussion and dialogue (What would Socrates say?) about the relations between Afrocentric proposals and the projects that Spring carefully considers earlier in the book. Spring may have reasons for this oversight. There is certainly no lack of caustic criticism on Afrocentrism in the mass media. However, Spring's failure to engage Asante stands out like a sore thumb in the context of his discussions of other theorists.

Finally, Spring's list of characteristics for democratic education is disappointing. After his careful argument and successful description of diverse philosophies, I wanted to hear more than that the goals for a democratic education include items such as "Students should not be asked to sactifice their physical needs and desires for a god, a state, or a ruler," and "Eliminate all 
forms of patriotic and nationalistic education" (p. 181). Since anarchists of various kinds have long held similar positions, there is nothing new here. The list also speaks to the limitations of libertarian-anarchism. For example, under "Political Structure," Spring lists, "Create political structures that maximize the ability of all citizens to share equal political power in educational decisions," and "Eliminate federal and state control of the curriculum, teacher education, and methods of instruction." In both cases, the really difficult questions are how to achieve these structural changes and what is the role of education/pedagogy in achieving them.

Despite these weaknesses, Spring has succeeded in writing a student's first textbook in philosophy of education. It provides easy access to many of the more important philosophers of education in the Western canon while at the same time demonstrating the value of critical reflection. His argument about the liberating potential of education and the elements of a democratic education could be used to structure courses and readings at both the graduate and undergraduate levels. His efforts to relate the discussions of theory to the practices that result from them could also help to stimulate discussions in teacher education programmes. Even the limitations of the book provide ample fodder for exploration. Perhaps the greatest value of this book is that in addition to accomplishing these things, it stimulates questions about the "wheels in the head" that shape us all.

Reviewed by Timothy J. Stanley, Université d'Ottawa

Linda Darling-Hammond (Ed.), Professional Development Schools: Schools for Developing a Profession (Professional Development and Practice Series). New York and London: Teachers College Press, 1994.

The central task of the current reform movement in education is nothing less than building and transforming schools that are struggling to achieve democratic ideals. The purpose of the Professional Development and Practice Series is to contribute to this historic transformation by presenting a variety of descriptions of practice-oriented research .... As new organizational arrangements and collaborative relationships are being forged and studied, old enduring problems are being looked at in new ways that are leading us to fresh insights .... The writers in this series are attempting to involve us in a dialog about action, participation, and change based on the best evidence. (From the Series Editor, v.)

As one teacher asserted: "We want to be involved in teacher education, that's what the bottom line is .... I feel like it is so important to us to send out good teachers, not just teachers, but good teachers ... . We have seen weak teachers .... If we are going to get the respect that is due our profession, we have got to take charge and build our profession up" (p. 187).

The nine chapters are the work of fourteen contributors; three are explicitly identified as teachers, three others as former teachers; most were participants in the projects they describe (p. 49). With the proliferation of "schooluniversity collaborations ... that call themselves PDSs [professional development schools]" (p. 2) and now, in Quebec, required contracts for the supervision 